VladylEna SOKYRSKa

Sumski Państwowy Uniwersytet Pedagogiczny im. Antona Makarenki / Sumy State Pedagogical University named after A.S. Makarenko

iD https://orcid.org/0000-0002-9983-3234

IRYNA KRUPENYA

Międzynarodowy Uniwersytet KiJowski /

KYIV InTERNATIONAL UnIVERSITY

iD https://orcid.org/0000-0002-3336-974X

Kateryna Didenko

Państwowy Uniwersytet Pedagogiczny im. Pawea Tyczyny w Umaniu /

Pavlo Tychyna Uman State Pedagogical University

(iD https://orcid.org/0000-0001-8406-173X

\title{
Relations between the RSFSR and the Ukrainian SSR in the 1920s: diplomatic and administrative-institutional aspects
}

STREsZCZENie

Stosunki między Rosyjską Federacyjną Socjalistyczną Republiką Radziecką a Ukraińską Socjalistyczną Republiką Radziecką w latach dwudziestych XX w.: aspekty dyplomatyczne $i$ administracyjno-instytucjonalne

\U artykule omówiono specyfikę stosunków między RFSRR a Ukraińską SRR V latach 1919-1929. Autorzy przedstawili stosunki pomiędzy rządami obu republik oraz działania strony rosyjskiej zmierzające do przekształcenia w państwo o charakterze unitarnym dość luźno powiązane ze soba początkowo elementy składowe państwa radzieckiego. Stosunki między RFSRR a Ukraińska SRR od początku obarczone były istotnymi wadami, ponieważ ta pierwsza przywłaszczyła sobie prawa przynależne związkowemu centrum.

W artykule wyjaśniono też rolę i miejsce stałych przedstawicielstw republik związkowych w Moskwie, jak również wpływ komisarzy (reprezentantów rządu ukraińskiego w Moskwie) na politykę sowieckiej Rosji wobec Ukrainy. Permanentne ignorowanie przez rząd w Moskwie potrzeb i oczekiwań Ukrainy skłoniło kierownictwo partii i rząd Ukraińskiej SRR do poszukiwania ochrony jej interesów 
gospodarczych na poziomie instytucjonalnym. Wraz z utworzeniem ZSRR zmienił się status prawny republik wchodzących w skład tego państwa. Stosunki między republikami straciły charakter międzypaństwowy. W miejsce dotychczas funkcjonujacych utworzono nowe przedstawicielstwa, które miały zapewnić utrzymywanie stałych powiązań między rządem RFSRR a rządami republik związkowych.

Słowa kluczowe: Rosyjska Federacyjna Socjalistyczna Republika Radziecka, Ukraińska Socjalistyczna Republika Radziecka, Związek Socjalistycznych Republik Radzieckich, stosunki rosyjsko-ukraińskie, polityka centralizacyjna, władza radziecka, stałe przedstawicielstwo

\section{AbSTRACT}

$\mathrm{T}$ he article discusses the specifity of the relations between the RSFSR and the Ukrainian SSR in 1919-1929. The authors present the relations between the goverments of the two republics and actions of the Russian side aiming to transforme into the unitary state, initially rather loosely connected among them the constituent elements of the Soviet state. Relations between RSFSR and the Ukrainian SSR were burdened with significant disavantages from the very beginning, as the former appropriates the rights of the union center.

The article explains also the role and the place of the permanent representations of the union republics in Moscow, as well as the influence of the commissioners (Ukrainian government representatives in Moscow) on Soviet Russia's policy towards Ukraine. Permenent ignoring by the government in Moscow of Ukraine's needs and expectations, prompted the leadership of the party and the government of Ukrainian SSR to seek protection of its economic interests at the institutional level. With the creation of the USSR, the legal status of the republics included in that state changed. Relations between the republics lost their interstate character. In place of the existing ones, new representations were established to ensure the maintenance of permanent ties between the government of the RSFSR and the governments of the union republics.

Keywords: RSFSR, Ukrainian SSR, Union SSR, Russian-Ukrainian relations, centralized politics, soviet power, permanent representation

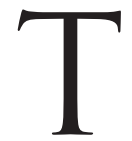

he collapse of the USSR, the problems of socio-political, economic, national and cultural transformations of the Soviet republics, the search for new forms of relations between them, the implementation of democratic reforms have become a challenge to the modern system of European and international security. Among the post-Soviet states, Ukraine and Russia are the largest actors in the territorial, demographic, economic and military dimensions. At the present stage historians have an important task to answer questions that make it difficult to find a way to their equal and effective cooperation on the principles of international 
law, mutually beneficial interests, taking into account the contradictory cultural and historical heritage.

The end of the First World War led to the destruction of the Russian Empire, which led to the liquidation of the political institution of the monarchical system of government and the formation of independent states on its territory. The classical empire went down in history, and imperial tendencies persisted in the ideology and theory of Russian great power. It manifested themselves in the fierce struggle against the Ukrainian People's Republic, in the interstate relations of the RSFSR and the Ukrainian SSR in the early 1920s, in opposition to the trend towards unification and building the national and cultural identity of the Ukrainian society, finally, in the consistently pursued policy of centralization. Tension in the political relations between the Ukrainian SSR and the RSFSR led to some confusion in the formation of the authorities that could ensure these relations.

In October 1917, the People's Commissariat for Nationalities of the RSFSR was established in Moscow to implement national policy $^{1}$. It created representations of the autonomous republics of the RSFSR. The heads of national missions formed the Council of Nationalities. The tasks of the People's Commissariat of the RSFSR determined the development and implementation of all measures that would ensure the cooperation of nationalities of the RSFSR, the interests of national minorities, the solution of controversial national problems.

Given the fact that Ukrainian national minorities also lived on the territory of the RSFSR, the Politburo of the Central Committee of the Communist Party (Bolsheviks) of Ukraine July 8, 1920, adopted a resolution on the establishment of a Ukrainian mission to the People's Commissariat of the RSFSR. Kharkiv delegated to Moscow the Board of Representatives of the Ukrainian SSR headed by Yurii Kotsyubynsky ${ }^{2}$. As an executive body at the Board, the following departments were formed: general, literary-publishing, organizational-instructing and the department of relations with Ukraine. The Central Ukrainian Department of People's

1 Zbirnyk zakonodavstva i rozporyadzhen' robitnycho-selyans'koho uryadu RRFSR, 1920, May 27, No. 45, article 202.

${ }^{2}$ Materialy do protokoliv No. 93-103 zasidan' politbyuro TSK KP(b) Ukrayiny, Tsentral'nyy derzhavnyy arkhiv hromads'kykh ob"yednan' Ukrayiny (Central State Archive of Public Associations of Ukraine) [hereinafter: CSAPAU], fund 1, description 6 , case 27, sheet 39 . 
Commissariat of the RSFSR was organized in Moscow. Six regional Ukrainian branches (Kyrgyz, Bashkir, Turkestan, Siberian, Far Eastern, and North Caucasus) were established in regions with a compact residence of Ukrainians.

Ukrainian branches acted in accordance to the directives and instructions of the Ukrainian government and the People's Commissariat of the RSFSR. All Ukrainian institutions (cultural, educational, scientific and economic), which were operated in the Ukrainian SSR, were subordinated to the Ukrainian Representation under the People's Commissariat of the RSFSR. The Ukrainian Representation, together with the Department of Education of National Minorities at the People's Commissariat, carried out cultural and educational work among Ukrainians living on the territory of the RSFSR, tried to provide partial or complete teaching of subjects in Ukrainian, promoted publishing activities, etc.

In addition, the People's Commissar of the Ukrainian SSR tried to organize in Moscow the Representation of the Ukrainian SSR, which would not be a part of the People's Commissariat of the RSFSR. It had to be a completely independent body of the Ukrainian SSR under the government of the RSFSR. The absence of such a body forced the Ukrainian Representation to the People's Commissariat to act as a liaison body between the People's Commissar of Ukraine and the People's Commissariats of the RSFSR. In this case, the Ukrainian Representation had a dual subordination: the Council of People's Commissars of the Ukrainian SSR and the People's Commissariat of the RSFSR, was guided by their instructions and orders, was accountable to these bodies.

By the middle of 1921, the People's Commissariat of the RSFSR abandoned the idea of representing the interests of Ukrainians in Russia. Within the People's Commissariat of the RSFSR, there remained 12 offices of autonomous entities and 9 departments, among which were Jewish, Crimean, Polish, Estonian, Latvian, and Finnish, but there was no Ukrainian ${ }^{3}$. As the Ukrainian SSR failed to become an autonomy within the RSFSR, the Kremlin considered it unnecessary to take care of the national and cultural needs of Ukrainians in Russia. The federal system of the RSFSR was logical, and the federal principle in relations with the Ukrainian SSR looked like an artificial institution.

${ }^{3}$ V. Yefimenko, Stvorennya Povnovazhnoho predstavnytstva USRR $v$ RSFRR, "Problemy istoriyi Ukrayiny: fakty, sudzhennya, poshuky" 2010, No. 19, p. 23. 
The Russian-Bolshevik occupation regime in Ukraine, which was hidden by the acronym Ukrainian SSR, also needed international legitimacy. The government of Soviet Ukraine made significant diplomatic efforts to convince foreign states of the legitimacy of its power in Ukraine and to recognize it as the only representative of the Ukrainian SSR in the international arena. After all, the right of independent relations with foreign states was one of the conditions of the sovereignty of the Ukrainian SSR. However, Soviet Russia tried to control all spheres of life of the national Soviet republics, despite their formally independent legal status in the early 1920s. However, control of the foreign policy activities of the Soviet republics was relative and Moscow could not influence Western countries.

The Soviet People's Commissar of the Ukrainian SSR established official political relations with foreign states but constantly encountered obstacles in the central authorities in Moscow. The legal right to pursue foreign policy in the Ukrainian Soviet government appeared after the signing on December 28, 1920 of an alliance agreement between the RSFSR and the Ukrainian SSR with recognizing the mutual sovereignty and independence of the parties. In view of this, in 1920-1923 the activities of the People's Commissariat of Foreign Affairs of the Ukrainian SSR were aimed at developing diplomatic relations with other states, improving domestic legislation within the competence of the People's Commissariat, maintaining contacts with foreign missions in the Ukrainian SSR. The Ukrainian Soviet government tried to organize in Moscow the Authorized Representation of the Ukrainian SSR as a completely independent institution of Ukraine under the government of the RSFSR. On December 13, 1920, on the basis of the Ukrainian mission to the People's Commissariat of the RSFSR, a diplomatic mission of the Ukrainian SSR was established under the RSFSR SNC, which became the first diplomatic mission of the Ukrainian SSR abroad and played an important role in the Ukrainian SSR's "embassy rights"4.

${ }^{4}$ V.A. Chekhovych, Postiyne Predstavnytstvo Rady Ministrivukrayins'koyi RSR pry Radi Ministriv Soyuzu RSR: istoriya i suchasnist', "Verkhovenstvo prava" 1992, issue 1, p. 128. 
On January 12, 1921, the Ukrainian diplomatic mission headed by Yurii Kotsyubynsky was officially accredited by the RSFSR government ${ }^{5}$. It became a mediator in the recognition of the Ukrainian SSR in the international arena, the signing of a number of diplomatic agreements, played an important role in establishing political and economic relations between the Ukrainian SSR and the Soviet republics and foreign states. Through the embassies of foreign states accredited in Moscow, the diplomatic mission became a mediator in the relations of the government of the Ukrainian SSR with foreign states. Assisted in organizing the activities of the People's Commissariat for Foreign Affairs of the Ukrainian SSR by supplying the texts of agreements with foreign countries, which had at its disposal the People's Commissariat of Internal Affairs of the RSFSR.

Priority on the agenda was the task of concluding agreements with countries that gained independence as a result of the collapse of the Russian Empire. The peculiarity of the contractual relations of the Soviet republics was that they had only a bilateral connection in relations with Soviet Russia. At the same time, there were no agreements between the Soviet republics themselves. Then all relations between them had to be carried out through official Moscow. This circumstance slowed down their economic initiative and increased economic and political dependence on the RSFSR. Its government gradually took over the role of the center of the entire former imperial territory, and the governments of the national republics were seen as subordinate administrative centers of their provinces. An important issue was to determine the form of representation of the Ukrainian SSR. The central departments were dominated by the concept of giving Russian ambassadors abroad the functions of representatives of the Ukrainian SSR, but this contradicted the declared Soviet independence and sovereignty of Ukraine, and the status that Ukraine had in international politics.

${ }^{5}$ Vykhidni dokumenty Postpredstva USRR pry Uryadisrsr ta dokumenty pro diyal'nist' Postpredstva USRR u Moskvi (protokol, polozhennya, instruktsiyi, dovidka, lystuvannya), Tsentral'nyy derzhavnyy arkhiv vyshchykh orhaniv vlady iupravlinnya Ukrayiny (Central State Archive of Supreme Bodies of Power and Government of Ukraine) [hereinafter: CSASBPGU], fund 3, description 1, case 547, sheet 84 . 
Despite the declared independence of the Soviet republics, the Kremlin tried to monitor them constantly. Given the nature of the relationship between the RSFSR and the Ukrainian SSR, determined by the VIII Congress of Soviets, the Ukrainian SSR received the right to have in European countries, especially with large Ukrainian emigrants, their independent representation only with political functions closely related to the RSFSR. Issues related to the economy, foreign trade, military affairs had to be resolved with the RSFSR together only. In all other countries, the representatives of Ukraine were part-time heads of diplomatic missions of the RSFSR ${ }^{6}$.

There are three periods in the activity of the Ukrainian diplomatic mission in Moscow. The first occurred in January-March 1921. The Ukrainian government actively cooperated with foreign missions in Moscow, formed an objective and favorable opinion of the Ukrainian SSR, and provided objective information about Ukraine. The second period was March-September 1921, during which the Ukrainian diplomatic mission concluded an agreement with Turkey on the repatriation of prisoners of war, treaties and a refugee convention with Lithuania, and offered citizenship and property rights to Latvian citizens in Ukraine. The third period concerned the autumn of 1921, when a treaty was concluded with Estonia, and negotiations were held with Germany and England. During this period, the development of the Asian direction of establishing foreign relations of the Ukrainian SSR. Thus, even given the independence of diplomatic agreements, the presence of the "older brother" proved to be an institutional and symbolic attribute, although the international subjectivity of the Ukrainian SSR took place.

With the signing of the Union Treaty on December 28, 1920, there was also a need to agree on economic plans between the Ukrainian SSR and the RSFSR to establish a shared plan and settle economic relations between the People's Commissariats of two republics. Foreign policy circumstances also required a demonstration of Ukrainian independence. On April 5, 1921, the AllUkrainian Central Executive Committee issued the Regulation

\footnotetext{
${ }^{6}$ N. D mytras evych, Reparatsiyni uhody Radnarkomu USRR yak instrument mizhnarodnoyi lehitymizatsiyi Ukrayins'koyi radyans'koyi derzhavy, "Zhurnal Kyyivs'koho universytetu prava" 2010, No. 2, pp. 65-67.
} 
"On the Authorized Representation for Economic Construction under the Workers 'and Peasants' Government of the RSFSR" The personnel of the Authorized Representation of the Ukrainian SSR for Economic Construction under the SNC of the RSFSR and the Ukrainian Diplomatic Mission in Russia were united. Since then, Ukrainian interests in Moscow (economic, political and diplomatic) have been represented by the only Authorized Representation of the Ukrainian SSR to the RSFSR SNC, headed by Mikhail Poloz ${ }^{8}$. He represented the economic interests of the Ukrainian SSR in all bodies of the RSFSR. The activities of this body of communication between the republics restrained the Russian Soviet leadership from subordinating Ukraine economically. The plenipotentiaries had a special role among other forms of communication between the Soviet republics and the RSFSR. They served as embassies and consulates, although their work differed greatly from similar institutions. Plenipotentiaries were a new form of cooperation institutions of the Soviet republics.

Here it is worth noting the nature of economic relations between the Soviet republics. With the issuing of the decree of the Central Executive Committee of June 1, 1919, the management of the basic branches of the Ukrainian SSR (military, financial, railway transport, the national economy, the post office, and the telegraph) was also concentrated in a single Russian board. The second return of the Bolsheviks to Ukraine prompted the All-Ukrainian Revolutionary Committee on January 28, 1920, to renew the previous decision to unite the activities of the Ukrainian SSR and the RSFSR ${ }^{9}$. The joint commissariats served the needs of both republics and acted under their joint control through the Central Executive Committee, which was a federal body. Only the commissariats of internal affairs, education, food, social security and health care resumed their activities as independent bodies. The manner and forms of relations between the two governments were determined by the introduction of the institution of authorized joint people's commissariats of the RSFSR under the government of the Ukrainian

7 Polozhennya pro protokol'nu chastynu NKVS URSR. Dyplomatychnyy korpus, akredytovanyy pry robitnycho-selyans'komu uryadi RRFSR. Sertyfikaty, povnovazhennya, doruchennya, vydani NKVS URSR, CSASBPGU, fund 4, description 1, case 616 , sheet 42 .

${ }^{8}$ V. Yefimenko, op. cit., p. 19.

9 Zbirnyk postanov VUTSVK 5-ho sklykannya, issue 1, Kharkiv 1921, p. 48. 
SSR. They were the direct executors of all, without exception, the activities of the relevant commissariats of the RSFSR, were part of the republican government as people's commissars. Such equality in the rights of the representatives of the government of the RSFSR in Ukraine with the members of the government of the Ukrainian SSR strengthened the position of the RSFSR in the general government in Ukraine and neutralized the influence of the Ukrainian government.

The preamble to the treaty of December 28, 1920 between the RSFSR and the Ukrainian SSR on military and economic union focused on the independence and sovereignty of both republics. However, the content of the agreement contradicted the declarations of the preamble itself. The governments of the RSFSR and the Ukrainian SSR declared seven People's Commissariats united: military and naval affairs, the Supreme Council of the National Economy, foreign trade, finance, labor, communications, post, and telegraph. According to the agreement and the resolution of the SNC of the Ukrainian SSR "On the Commissioners of the RSFSR under the Ukrainian SSR People's Commissar" of January 25, 1921 , the joint people's commissariats of both republics were part of the RSFSR People's Commissariat and had in the Ukrainian SSR government their commissioners controlled by the All-Ukrainian Central Executive Committee ${ }^{10}$. The commissioners were members of the government of the Ukrainian SSR as people's commissars. They had a double subordination, as they were guided in their activities by decrees and resolutions of the central authorities of the RSFSR and Ukrainian SSR. Under the commissioners, the Office of the Commissioner of the relevant People's Commissariat of the RSFSR under the SNC of the Ukrainian SSR was created. The commissioners were guided exclusively by the laws of the RSFSR and the orders of the relevant Russian People's Commissariats.

With the formation of the Ukrainian SSR in July 1923, there was a need to make changes to the system of branch government of all union republics, including the Ukrainian SSR. The People's Commissariats of the Ukrainian SSR were divided into two groups: all-Union (single for the whole Union), united (directive), whose bodies in the union republics were the People's Commissariats

${ }^{10}$ Ibidem, p. 67. 
of the same name, and republican. The All-Union People's Commissariats included: foreign affairs, military and naval affairs, foreign trade, communications, post and telegraph. The relevant people's commissariats in the union republics ceased to function. Instead, they created the Office of the Commissioner of the relevant All-Union People's Commissariat under the Government of the Republic. The government of each union republic received five commissioners. The second group of People's Commissariats consisted of the Supreme Council of the National Economy, the People's Commissariats of Food, Labor, Finance, and the Workers 'and Peasants' Inspectorate (RSI). They were subordinated to the CEC and the SNC of the Union Republic, and complied with the directives of the relevant people's commissariats of the Ukrainian SSR. The People's Commissariats of Land Affairs, Health Care, Social Security, Education, Internal Affairs, and Justice remained republican.

In this way, the Central Committee of the $\mathrm{RCP}(\mathrm{B})$, through its local bodies, tried to control the united People's Commissariats operating in the territory of the union republics. In their activities, they were completely subject to the will of the center, which tried to control the union republics and their strategic branches, and did not allow them to develop independently economically.

The Ukrainian Soviet leadership increasingly argued that cultural and national autonomy were not enough for the Ukrainian SSR to be a successful republic. Ukraine's economic needs were systematically ignored by official Moscow. By demanding that the Ukrainian SSR fulfill its economic tasks, the Kremlin ignored Ukraine's needs and unjustifiably reduced the funds promised to it. In the letter to V. Lenin, dated October 1920, Christian Rakovsky pointed out the incomprehensibility in relations between the two republics ${ }^{11}$.

The blatant disregard for Ukraine's needs prompted the Communist Party-Soviet leaders of the Ukrainian SSR to seek means of protecting the republic's economic rights at the institutional level. One of such protective mechanisms was the representation of the Ukrainian government in the central economic bodies.

${ }^{11}$ Fotokopiya Polozhennya pro ukrayins'ke Predstavnytstvo pry Narodnomu Komisariati v spravakh natsional'nostey RSFRR. Fotokopiya protokolu narady zaviduyuchykh natsional'nymy viddilamy pry TSK KP(b)U, CSAPAU, fund 57, description 2 , case 432 , sheet 2 . 
In the letter to $\mathrm{V}$. Lenin, Ch. Rakovsky raised the question of the full functioning of the Ukrainian Promburo, giving it greater freedom of action, the expediency of accepting a representative of the Ukrainian Industrial office at the Supreme Council of the National Economy, "wherever he defended our interests and, most importantly, would keep us informed of common issues"12. Therefore, the idea of creating a representative office of the Ukrainian SSR under the government of the RSFSR was part of a plan to strengthen Ukraine's economic independence.

In November 1920, at the V Conference of the $\mathrm{CP}(\mathrm{B}) \mathrm{U}$, the thesis on the need for autonomy in the management of the Ukrainian economy was approved ${ }^{13}$. It was recognized that the condition for the revival of Ukraine is the independence of the Ukrainian apparatus. Russia's Soviet policy toward the Ukrainian SSR was based on double standards. On the one hand, the relative independence of the Ukrainian SSR in decision-making, including economic ones, was formally demonstrated to the international community. On the other hand, in real political practice the creation of a line in incorporation is realized. Ever since the signing of the Union Treaty on December 28, 1920, the need to agree on economic plans of the Ukrainian SSR and the RSFSR has always been used to establish a shared plan and settle economic relations between the People's Commissariats of the two republics. Foreign policy circumstances also require a demonstrative demonstration of Ukrainian independence. In the words of Ch. Rakovsky, spoken by him on March 2, 1921, at the V All-Ukrainian Congress of Soviets shortly before the ratification of the "Union of Workers 'and Peasants' Agreement between the RSFSR and the USSR": "We should not give the international counterrevolution the reason to claim there is no international treaty under which the RSFSR would recognize the right of Ukrainian workers and peasants to arrange their economic life as they wish" ${ }^{14}$.

We must state that before the formation of the Ukrainian SSR, the Soviet republics were sovereign socialist states and acted as independent subjects in international relations. With the development of federal relations between the republics, there was a need

12 Ibidem, sheet 5 .

13 Zvit TSK KP(b)U vid 1 kvitnya do 1 lystopada 1920 r. Do V Vseukrayins'koyi partkonferentsiyi, Kharkiv 1920, p. 14.

${ }^{14}$ Visnyk 5-ho Vseukrayins'koho z'yizdu Rad, March 4, 1921, No. 6, p. 133. 
to create special inter-republican institutions capable of maintaining permanent ties between the governments of the RSFSR and the republic. Such bodies were the authorized representations of the republics in Moscow, which began to be established in 1921.

After the appointment of Yurii Kotsyubynsky as the Authorized and Representative of the Ukrainian SSR in Vienna in early December $1921^{15}$, Ukraine's trade representation in Soviet Russia was merged with the political one. The personnel of the Authorized Representation of the Ukrainian SSR for Economic Construction under the Council of People's Comissars of the RSFSR and the Ukrainian diplomatic mission in Russia was merged. Since then, Ukrainian interests in Moscow (economic, political and diplomatic) have been represented by the only Authorized Representation of the Ukrainian SSR at the RSFSR SNC, headed by M. Poloz ${ }^{16}$. He remained the head of this department until the legalization of the Ukrainian SSR in July 1923. By a resolution of the Politburo of the Central Committee of the $\mathrm{CP}(\mathrm{B}) \mathrm{U}$ of December 13, 1921, V. Lyakh was appointed First Secretary of the Plenipotentiary ${ }^{17}$. He had experience in such positions in the Ukrainian mission to the People's Commissariat of the RSFSR and in the diplomatic mission of the Ukrainian SSR.

During this period, the plenipotentiary missions, in essence, structure and other features, although they were diplomatic bodies of the republics, but in fact their competence covered a wider range of issues. They were the liaison body of these republics not only with the government of the RSFSR, but also, if necessary, with foreign countries through their embassies in Moscow. Authorized representations were state institutions new in world practice, bodies aimed at promoting cooperation between the republics. Although on a number of issues the embassy still had the function of a diplomatic mission. The economic service of the embassies in Moscow was entrusted to the Bureau for the Service of Foreigners of the NKVD of the RSFSR ${ }^{18}$.

15 M. Mazynchuk, Uchast' Yu. Kotsyubyns'koho u radyans'kiy zovnishniy politytsi, "Ukrayinoznavstvo" 2013, No. 3-4, p. 44.

${ }^{16} \mathrm{~V}$. Yefimenko, op. cit., p. 31.

17 Materialy do protokoliv No. 45-55 zasidan' Politbyuro TSK KP(b)U), CSAPAU, fund 1 , description 6 , case 35 , sheet 64 .

18 A. Krokhotkin, Postoyannue Predstavytel'stva - orhanb svyazy Sovetov Mynystrov soyuznukh respublyk s Sovetom Mynystrov SSSR, "Radyans'ka derzhava i prvo" 1962, No. 11, p. 89. 
Representations were given the main task - to promote the implementation of economic plans of the republics, strengthening the Soviet system and friendly relations between them. To achieve this goal, the embassies were given the right to apply on behalf of the government of their republic with representations and petitions to the Central Executive Committee, the SNC and the People's Commissariats of the RSFSR on all matters relating to the life of the republic. The embassies were no longer purely diplomatic missions. The need for such statuses has disappeared, taking into account the formation of federal relations between the republics.

From November 1921 to January 1922, the Office of the Embassy continued to function as the Office of the Authorized Representation of the Ukrainian SSR for Economic Construction. Since January 1922, the Department of Affairs has been working on the basis of the only Authorized Representative of the Ukrainian SSR in the RSFSR and consisted of an office, an accounting department, and an economic unit ${ }^{19}$. Representations of the central administrative bodies of Ukraine in Moscow were located in the building of the Embassy: People's Commissariat of Internal Trade of the Ukrainian SSR, the Commissioner of Railways, RATAU, the Commissioner of the People's Commissariat of Education, All-Ukrainian Cooperative Union of the People's Commissariat of Land Affairs, Ukrainian Sugar Trust. The staff of the Authorized Representation of the Ukrainian SSR in Moscow numbered 75 people.

It was headed by the Authorized Representative, who had a deputy with all the rights of the Commissioner. He previously had the right to be present at the meetings of the Labor and Defense Council, where he had a casting vote, as well as with the right of an advisory vote in the Council of People's Comissars of RSFSR and the Presidium of the All-Ukrainian Central Executive Committee. As already mentioned above, M. Poloz was the head of the Authorized Representative of the Ukrainian SSR to the Government of the RSFSR. By a resolution of the Politburo of the Central Committee of the CP(B)U of April 4, 1922, Anton Prykhodko was appointed Deputy Authorized Representative of the Ukrainian SSR in the RSFSR. After that, the Secretary of the Central Committee Dmytro Manuilsky addressed the Central Executive Committee with a proposal to approve A. Prykhodko as M. Poloz's deputy

${ }^{19}$ Dopovid' pro robotu planovoho byuro Povpredstva USRR, CSASBPGU, fund 3, description 1 , case 95, sheet 1 . 
and in the Labor and Defense Council ${ }^{20}$. The authorized representation of the Ukrainian SSR in the RSFSR consisted of a secretariat, a diplomatic department, a planning bureau, a material bureau, an information department, the management of the affairs of the Embassy, accounting, and the economic part.

In its work, the Ukrainian SSR embassy in Moscow set the task of strengthening the international position of the Ukrainian SSR, promoting closer relations with other states through diplomatic means on the basis of the common political line of the Ukrainian government and directives of the People's Commissariat of Internal Affairs of the Ukrainian SSR in coordination with the People's Commissariat of Internal Affairs of the RSFSR. Ukraine's embassy in Moscow had close relations with foreign missions of Turkey, Persia, Afghanistan, the Far Eastern Republic, China, Belarus, Azerbaijan, Khorezm, Georgia, Armenia, Bukhara, England, Germany, Austria, Lithuania, Poland, Estonia and Finland, Sweden, Norway, Italy. Mutual exchanges of visits were made with all these Missions $^{21}$.

For a long time, the Authorized Representation of the Ukrainian SSR in the RSFSR did not have a clear legal form. On May 31, 1922, a meeting of the commission chaired by the People's Commissar of Justice Mykola Skrypnyk took place in Kharkiv, at which the issue of the position of the Authorized Representation of the Ukrainian SSR in the RSFSR was also considered. The commission included authorized representative M. Poloz, Deputy People's Commissar for Foreign Affairs V. Yakovlev ${ }^{22}$. The Commission decided that it was inexpedient to develop "Regulations on the Authorized Representation of the Ukrainian SSR in the RSFSR". It was enough to be guided by the "Regulations on the Representations of the Ukrainian SSR", approved by the resolution of the Presidium of the All-Ukrainian Central Executive Committee of September 6, 1921, the general provisions on the Authorized Representation of the Ukrainian SSR. Also the provisions on the economic

20 Zapys telefonnykh rozmov Povpredstva USRR pryuryadi RSFRR $z$ ukrayins'kym uryadom u Kharkovi, CSASBPGU, fund 3, description 1, case 138, sheet 15 .

${ }^{21}$ Dopovid' pro robotu planovoho byuro Povpredstva USRR, CSASBPGU, fund 3 , description 1 , case 95 , sheet 34 .

${ }^{22}$ Materialy pro orhanizatsiyu torhivel'nykh predstavnytstv za kordonom i ukladennya torhivel'nykh dohovoriv; pro diyal'nist' rosiys'kykh i ukrayins'kykh emihrantiv za kordonom. Polozhennya pro Povnovazhne predstavnytstvo USRR pry uryadi RSFRR, CSASBPGU, fund 4, description 1, case 15, sheet 229. 
representation of the Ukrainian SSR in the RSFSR and the resolutions of the All-Ukrainian Central Executive Committee, the People's Commissar and the Ukrainian Academy of Sciences in the part concerning the sphere of its activity.

The question was raised about the presence of Ukrainian diplomatic representative in the Labor and Defense Council, where he would have a decisive vote, as well as an advisory vote in the People's Commissariat of the RSFSR and the Presidium of the Central Executive Committee. All representations of individual People's Commissariat and other central institutions located on the territory of the RSFSR were subordinated to the Embassy, which coordinated and coordinated their activities. These missions performed the tasks of the Authorized Representative and were accountable to him.

In August 1922, a resolution of the All-Ukrainian Central Executive Committee and the SNC of the Ukrainian SSR was issued, approving the "Regulations on the Authorized Representative of the Ukrainian SSR to the Government of the RSFSR" ${ }^{23}$. According to this normative act, the Commissioner of the Ukrainian SSR was a member of the Labor and Defense Council and its planning bodies with the right to a casting vote, and a member of the Russian government with the right of an advisory vote. The Ukrainian Plenipotentiary had the right to be present at meetings of the All-Russian CEC and the Soviet People's Commissariat and other central bodies of the RSFSR. In these bodies he had the right to vote on issues that directly or indirectly affected the interests of Ukraine. In fact, its main function was to protect the interests of Ukraine. In case of their violations, he had the right to demand the suspension of actions or regulations for further coordination with the relevant bodies of the Ukrainian SSR.

The embassy was given the opportunity to represent the interests of the Ukrainian SSR in all authorities of the RSFSR. Contributed to the proper and timely resolution of all issues received from the Ukrainian SSR and the implementation of the RSFSR bodies of all assignments and tasks given by the All-Ukrainian Central Executive Committee, the SNC and the Ukrainian Academy of Sciences. The mission was to regulate and coordinate the current relations between the People's Commissariats of the Ukrainian SSR and the RSFSR in the process of implementing a single plan of the Soviet government, agreeing a single economic plan of the

${ }^{23}$ Ibidem, sheet 235. 
Ukrainian SSR with the RSFSR State Plan to establish a federal plan. Carried out the general management and control over the activities of all persons who were sent by the departments of the Ukrainian SSR to the RSFSR.

The Authorized Representation in Moscow was responsible for resolving disputes and resolving misunderstandings that arose between the People's Commissariats and the Commissioners of the People's Commissariats of the Ukrainian SSR with the relevant People's Commissariats of the RSFSR. To do this, the Embassy was sent the necessary materials, copies of the relations of these institutions to resolve controversial issues. The embassy ensured that all statements made by representatives of individual people's commissariats to the People's Commissariats of the RSFSR and to central institutions were urgently transmitted in copies to the relevant People's Commissariats and central institutions of the Ukrainian SSR.

The Authorized Representation of the Ukrainian SSR to the Government of the RSFSR, in addition to performing its direct functions, was also the center of information about Ukraine in Moscow. A library was created at the Embassy, where all Ukrainian legislation could be presented. This was one of the necessary conditions that would ensure the work of the Embassy ${ }^{24}$. In order to exchange information more fully, the All-Ukrainian Publishing House and the provincial publishing houses were invited to send to the Authorized Representation of the Ukrainian SSR in Moscow several copies of all publications published both in the center and in the field.

The People's Commissariat for Foreign Affairs of the Ukrainian SSR was to ensure the organization of regular courier communication between the central bodies of the Ukrainian SSR and the Embassy in Moscow. For this purpose, regular, at least twice a week, courier flights were established between the SNK of the Ukrainian SSR and the Post Office in Moscow. All central institutions of the Ukrainian SSR were obliged to send through these couriers all the materials intended for the Embassy.

${ }^{24}$ Postanova RNK USRR pro Malyy Radnarkom. Vytyahy iz protokoliv zasidan' RNK USRR pro povnovazhennya Postiynoho Predstavnytstva USRR v RSFRR, CSASBPGU, fund 3, description 1 , case 59, sheet 10 . 
Thus, the Authorized Representation of the Ukrainian SSR to the government of the RSFSR became an inter-republican institution, which contributed to the development of federal relations between the republics. With the formation of the Ukrainian SSR, the legal status of the contracting republics changed. Now they became union republics. Accordingly, the status of their plenipotentiaries in the Ukrainian SSR government changed. Plenipotentiaries lost the functions of foreign relations, ceased to be called "plenipotentiaries" and were permanently under the government of the Ukrainian SSR. In view of this, the Permanent Representation of the USSR to the Government of the Ukrainian SSR was established in July 1923 to replace the Authorized Representation. From 1924, the following republics had their representations at the USSR SNK: the Russian SFR (O. Svidersky was the permanent representative), the Belarusian SSR (M. Moroz), and the Transcaucasian SSR (S. Ter-Gabrielyan) ${ }^{25}$.

By order of the Permanent Representation, its staffs of 46 people were formed. The post of Permanent Representative of the Ukrainian SSR to the Government of the USSR and his deputy, who had clearly defined powers, were introduced ${ }^{26}$. On August 3, M. Poloza was approved by the head of the State Plan of the Ukrainian SSR. The Permanent Representation of the Ukrainian SSR to the Government of the USSR was headed by A. Prykhodko. He was responsible for the general management of all affairs of the Representation, monitoring the observance of the USSR Constitution in matters concerning the union republics, maintaining contact between the Central Executive Committee of the Union and the All-Ukrainian Central Executive Committee, the activities of the Administrative and Financial Commission (in the case of estimated loans), People's Commissariat of Education.

According to the Regulations and in accordance with the Union legislation, the Permanent Representation of the Ukrainian SSR to the Government of the USSR had the right to participate in the legislative, administrative and economic activities of the highest

${ }^{25}$ Vykhidni dokumenty Postpredstva USRR pry uryadi SRSR, posvidchennya pro pravo vidviduvannya zasidan' tsentral'nyy orhaniv upravlinnya SRSR, CSASBPGU, fund 3, description 1, case 561, sheet 127.

${ }^{26}$ Nakazy Postpredstva USRR pry uryadi SRSR poosobovomu skladu i shtaty ta posvidchennya spivrobitnykiv Postpredstvausrr pry uryadi SRSR, CSASBPG, fund 3, description 1 , case 381, sheet 12 . 
authorities of the USSR. In particular, the competence of the Permanent Representation included the following: participation in the activities of the legislative bodies of the USSR; carrying out through the highest authorities of the USSR legislative proposals of the government of the Ukrainian SSR. On behalf of the highest authorities of the Ukrainian SSR, the Permanent Representation had the right to submit to the Presidium of the Central Executive Committee, Council of People's Commissars and Labor and Defense Council of the USSR draft laws, decrees, amendments, as well as to submit on behalf of the Ukrainian SSR draft resolutions and orders of an administrative nature. The post-mission provided independent opinions on draft decrees and other acts considered by the highest authorities of the USSR, which had all-Union significance or concerned the interests of the Ukrainian SSR.

Through the Permanent Representation of the Ukrainian SSR to the Government of the USSR, the interests of the Ukrainian SSR were protected in the highest administrative bodies of the USSR, including the All-Union People's Commissariats. Due to his stay in Moscow, the measures within the competence of the United People's Commissariats of the USSR were coordinated with the measures of the People's Commissariats of the same name of the Ukrainian SSR. The powers vested in them by the Post Office provided an opportunity to enter into relations with the All-Union and Russian People's Commissariats, to raise before them issues of concern to the highest authorities of the Ukrainian SSR. In accordance with the instructions of the Ukrainian SSR, the activities of trade, industrial and economic organizations of the Ukrainian SSR operating within the USSR were monitored ${ }^{27}$.

The effective functioning of any state body depends on the proper organizational and staffing structure and legal regulation of its activities. On February 14, 1925, the resolution "On the States of the Permanent Representation of the Ukrainian SSR to the Government of the USSR" was issued. According to this resolution, the Permanent Representation of the USSR in Moscow included 55 people. As under the previous provision, the Permanent Mission was headed by the chief of the Post and his two deputies. An economic and legal bureau was formed, which included

${ }_{27}$ Materialy pro orhanizatsiyu i diyal'nist' Upravlinnya Upovnovazhenoho Narkomfinu RSFRR pry Radnarkomi USRR ta yoho yurydychnoho viddilu (protokoly, narysy, zvity, tablytsi, zayavy, CSASBPGU, fund 30, description 1, case 388, sheet 64 . 
commissioners for finance, economics, domestic and foreign trade, jurisprudence, health care, education and culture, industry, agriculture, and their deputies. The Secretariat of the Post Office consisted of 20 people and the administrative and economic part - of 19 people $^{28}$.

The main task of the Permanent Representation of the Ukrainian SSR to the Government of the USSR was to streamline and improve relations with the highest bodies of the Ukrainian SSR and the USSR. The formation of the Permanent Representation of the Ukrainian SSR to the USSR government was not without its troubles. Inconsistent policy in this direction of the Ukrainian Soviet leadership, dispersion in the activities of the central authorities of the Ukrainian SSR, the lack of a unified and clear state line caused the loss of Ukraine's position in the all-Union construction. The situation was negatively affected by the fact that, along with the Embassy, which represented the Ukrainian SSR as a whole, there were a number of representative offices of individual Ukrainian People's Commissariats that claimed complete independence from the Embassy and were not connected. Even the People's Commissariats appointed and financed their representatives without the sanction of the Ukrainian government and with the proper coordination of the Ukrainian SSR Embassy in Moscow. This unbalanced its activities, undermined its authority as the only central body representing the interests of the republic.

With the strengthening of totalitarian tendencies in the management of the Soviet state, all tasks performed by the Ukrainian Permanent Representation in Moscow were reduced to participation in the preliminary development and preparation of legislative materials of all-Union importance, both in Ukrainian authorities in Moscow and in the Union People's Commissariats. various departmental and non-departmental commissions. The Permanent Representation was also involved in their further implementation through the highest authorities of the Union, coordination of this work with the Ukrainian People's Commissar. Another group of tasks was more specific in nature and was expressed in the settlement of more practical issues in the field of various people's commissariats, funding issues and in obtaining various certificates and materials of interest to Ukrainian people's commissariats.

${ }^{28}$ Zbirnyk zakoniv i rozporyadzhen' robitnycho-selyans'koho uryadu Ukrayiny 1925, part 5, article 102 . 
The Permanent Representation often had to eradicate the mixing of the activities of the RSFSR authorities with the activities of the allied bodies. Often, Union regulations were issued in addition to the laws of the RSFSR or as resolutions extending the resolutions of the RSFSR to the entire territory of the Union, and so on.

It was necessary to accustom the allied authorities to the fact that the Representation of the Ukrainian SSR was not an accidental institution. It was a body of the union republic, which had a mandate from the Ukrainian government to conduct issues related to the Ukrainian SSR, through union bodies and union legislation. There were cases, especially often with the People's Commissariat of Finance of the USSR, when the solution of important issues for Ukraine was delayed for months and not submitted in time for consideration by the Labor and Defense Council and the Council of People's Commissars of the USSR. The embassy had to fight the efforts of the Russian and allied authorities to bypass the Ukrainian Representation, to ignore its presence in Moscow. The work of the Post Office was aggravated by the unregulated relations with the Labor and Defense Council and the Soviet People's Commissar of the USSR ${ }^{29}$.

In addition, the Permanent Representation of the Ukrainian SSR to the USSR government acted as a liaison body of the Council of People's Commissars of the USSR with the People's Commissar of the Ukrainian SSR and the governments of the union republics in the field of all-Union and local construction. The Permanent Representation often acted as a buffer in the "union center-republic" relations, preventing the complete subordination of the activities of the Ukrainian authorities and the interests of the republic to the all-Union (in fact, Russian) ones.

Excessive centralization of government, which began in the mid-1920s, caused an unjustified narrowing of the rights of the Soviet republics, the competence of its bodies. In 1931-1932, the system of economic management in the USSR was restructured. The economy, which was mainly of local importance, remained under the control of the people's commissars of the union republics. Under these conditions, the competence of the Soviets of People's Commissars of the Union Republics, and consequently of their permanent representations to the Union Government, changed.

${ }^{29}$ Zapys telefonnykh rozmov Povpredstva USRR pryuryadi RSFRR z ukrayins'kym uryadom u Kharkovi, CSASBPGU, fund 3, description 1, case 138, sheet 4 . 
As a result, the competence of the Permanent Representation of the Ukrainian SSR to the USSR government also changed. Its role in solving issues of economic and cultural construction, in legislative activity was narrowed.

Thus, the Permanent Representations of the Soviet republics to the government of the USSR performed an important function of protecting their interests in the all-Union construction. The Ukrainian Permanent Representation played a special role in preserving the status of the union republics, in compliance with the Constitution of the USSR in terms of ensuring this status. Thanks to the balanced and consistent position of the Ukrainian Embassy in Moscow, it was possible to avoid the complete subordination of the Soviet republics to the Russian authorities and to prevent, as far as possible, the complete domination of the RSFSR in the process of union building.

\section{Bibliography}

\section{Archival sources}

Tsentral'nyy derzhavnyy arkhiv hromads'kykh ob"yednan' Ukrayiny (Central State Archive of Public Associations of Ukraine) [CSAPAU]

Fotokopiya Polozhennya pro ukrayins'ke Predstavnytstvo pry Narodnomu Komisariati v spravakh natsional'nostey RSFRR. Fotokopiya protokolu narady zaviduyuchykh natsional'nymy viddilamy pry TSK KP(b)U, fund 57, description 2, case 432, 5 sheets.

Materialy do protokoliv No. 45-55 zasidan' Politbyuro TSK KP(b)U), fund 1, description 6, case 35, 161 sheet.

Materialy do protokoliv No. 93-103 zasidan' politbyuro TSK KP(b) Ukrayiny, fund 1 , description 6 , case 27,239 sheets.

Tsentral'nyy derzhavnyy arkhiv vyshchykh orhaniv vlady iupravlinnya Ukrayiny (Central State Archive of Supreme Bodies of Power and Government of Ukraine) [CSASBPGU]

Dopovid' pro robotu planovoho byuro Povpredstva USRR, fund 3, description 1 , case 95, 120 sheets.

Materialy pro orhanizatsiyu i diyal'nist' Upravlinnya Upovnovazhenoho Narkomfinu RSFRR pry Radnarkomi USRR ta yoho yurydychnoho viddilu (protokoly, narysy, zvity, tablytsi, zayavy, fund 30, description 1, case 388, sheet 64.

Materialy pro orhanizatsiyu torhivel'nykh predstavnytstv za kordonom i ukladennya torhivel'nykh dohovoriv; pro diyal'nist' rosiys'kykh i ukrayins'kykh emihrantiv za kordonom. Polozhennya pro Povnovazhne predstavnytstvo USRR pry uryadi RSFRR, fund 4, description 1, case 15, 229 sheets. 
Nakazy Postpredstva USRR pry uryadi SRSR poosobovomu skladu i shtaty ta posvidchennya spivrobitnykiv Postpredstvausrr pry uryadi SRSR, fund 3, description 1, case 381, 34 sheets.

Polozhennya pro protokol'nu chastynu NKVS URSR. Dyplomatychnyy korpus, akredytovanyy pry robitnycho-selyans'komu uryadi RRFSR. Sertyfikaty, povnovazhennya, doruchennya, vydani NKVS URSR, fund 4, description 1, case 616,139 sheets.

Postanova RNK USRR pro Malyy Radnarkom. Vytyahy iz protokoliv zasidan' RNK USRR pro povnovazhennya Postiynoho Predstavnytstva USRR v RSFRR, fund 3 , description 1 , case 59,87 sheets.

Vykhidni dokumenty Postpredstva USRR pry uryadi SRSR, posvidchennya pro pravo vidviduvannya zasidan' tsentral'nyy orhaniv upravlinnya SRSR, fund 3, description 1, case 561, 129 sheets.

Vykhidni dokumenty Postpredstva USRR pry Uryadisrsr ta dokumenty pro diyal'nist' Postpredstva USRR u Moskvi (protokol, polozhennya, instruktsiyi, dovidka, lystuvannya), fund 3, description 1, case 547, 284 sheet.

Zapys telefonnykh rozmov Povpredstva USRR pryuryadi RSFRR $z$ ukrayins'kym uryadom u Kharkovi, fund 3, description 1, case 138, 62 sheets.

\section{Printed sources}

Visnyk 5-ho Vseukrayins'koho z'yizdu Rad, March 4, 1921, No. 6.

Zbirnyk postanov VUTSVK 5-ho sklykannya, issue 1, Kharkiv 1921.

Zbirnyk zakoniv i rozporyadzhen' robitnycho-selyans'koho uryadu Ukrayiny 1925, part 5, article 102.

Zbirnyk zakonodavstva i rozporyadzhen' robitnycho-selyans'koho uryadu RRFSR, 1920, May 27, No. 45, article 202.

Zvit TSK KP(b)U vid 1 kvitnya do 1 lystopada 1920 r. Do V Vseukrayins'koyi partkonferentsiyi, Kharkiv 1920.

\section{STudies}

Chekhovych V.A., Postiyne Predstavnytstvo Rady Ministrivukrayins'koyi RSR pry Radi Ministriv Soyuzu RSR: istoriya i suchasnist', "Verkhovenstvo prava" 1992, issue 1, pp. 127-131.

Dmytrasevych N., Reparatsiyni uhody Radnarkomu USRR yak instrument mizhnarodnoyi lehitymizatsiyi Ukrayins'koyi radyans'koyi derzhavy, "Zhurnal Kyyivs'koho universytetu prava" 2010, No. 2, pp. 65-67.

Krokhotkin A., Postoyannue Predstavytel'stva - orhanu svyazy Sovetov Mynystrov soyuznukh respublyk s Sovetom Mynystrov SSSR, "Radyans'ka derzhava i prvo" 1962, No. 11, pp. 89-97.

Mazynchuk M., Uchast' Yu. Kotsyubyns'koho u radyans'kiy zounishniy politytsi, "Ukrayinoznavstvo" 2013, No. 3-4, pp. 43-47.

Yefimenko V., Stvorennya Povnovazhnoho predstavnytstva USRR $v$ RSFRR, "Problemy istoriyi Ukrayiny: fakty, sudzhennya, poshuky" 2010, No. 19, pp. 16-33. 
About the Authors:

Prof. Vladylena Sokyrska - Professor of the Department of World History, International Relations and Methods of Teaching Historical Disciplines of Sumy State Pedagogical University, Ukraine. Doctor of Historical Sciences (2018), Professor (2021). Author of 140 publications, two monographs, 12 textbooks. Editor-in-Chief of the scientific journal "Consensus", a member of the editorial board of scientific journals: "Przegląd Nauk Historycznych", "Scientific Papers of Vinnytsia Mykhailo Kotsyiubynskyi State Pedagogical University. Series: History”. Member of the National Union of Local Historians of Ukraine.

Research interests: history of international relations, socio-political and economic processes of the twentieth century, Russian-Ukrainian relations of the 1920s1930s, scientific biography.

\vlada.sokirskaya@ukr.net

Assoc. prof. Iryna Krupenya - Associate professor with the International Relations Department of Kyiv International University, Ukraine. Candidate of Political Science (2017). Author of 40 publications, two monographs, two textbooks.

Research interests: international relations, regional processes and security issues in Southeast Asia, Russian-Ukrainian relations.

24tokiss@gmail.com

PhD Kateryna Didenko - Candidate of Historical Sciences, Lecturer of the Department of World History and Teaching Methods at Pavlo Tychyna Uman State Pedagogical University, Ukraine. The Author of 48 publications. Member of All-Ukrainian Union of Regional Ethnographers.

Research interests: socio-economic and political history of Ukraine during the period of 1920-1930s, scientific intelligentsia, USSR scientists, the activity of All-Ukrainian Committee of Scientists' Assistance, Central Commission on Improving the Welfare of Scientists.

\ didenkokaterina28@gmail.com 